UDC 332.2:528.9:004.01

\title{
CONCEPTUAL APPROACHES TO THE FUNCTIONING OF THE AUTOMATED LAND MONITORING SYSTEM
}

Y.M. Dorosh, Doctor of Economics Sciences, corresponding member of the National Academy of Agrarian Sciences of Ukraine, Land Management Institute of the National Academy of Agrarian Sciences of Ukraine e-mail: landukrainenaas@gmail.com

Tarnopolskyi A.V., Land Management Institute of the National Academy of Agrarian Sciences of Ukraine e-mail: landukrainenaas@gmail.com

Ibatullin Sh.I., Doctor of Economics Sciences, professor, member of the National Academy of Agrarian Sciences of Ukraine, Land Management Institute of the National Academy of Agrarian Sciences of Ukraine e-mail: shamilibatullin@gmail.com

\footnotetext{
Abstract. The goals and objectives of land monitoring and soil quality control are substantiated, including monitoring of economic and legal condition of lands, their transactions and quality of soils, assessment and forecast of changes in order to provide public administration and local governments with relevant information for developing proposals and implementing prevention of negative trends in land use.

The need to implement a system of land monitoring is stated because of systematic deterioration of the quantitative accounting of land, the actual lack of accounting for the quality of land, the requirements for the development of market land relations.

The necessity to take into account the principles and standards of the national infrastructure of geospatial data is substantiated. Directions have been formed in which the results of land monitoring can be used to regulate land relations and make management decisions regarding land use and the formation of land turnover.

Among the key issues that need to be considered when creating a land monitoring system are: the need to use new information technologies, a list of monitoring objects; attribute data of monitoring objects; unified standards and data formats; tools to ensure the reliability and updating of data, including by detecting anomalies and correcting errors in the data; mechanisms of information interaction between all participants of the monitoring process.
} 
Keywords: land resources, land monitoring, automated management systems, geospatial data infrastructure, land management, land cadastre, information-analytical system.

Formulation of the problem. The privatization of collective and state farm lands in Ukraine, which was the essence of the first stage of land reform, ignored an important aspect of land regulation and land management such as land monitoring and soil quality control. Norms, rules and standards for land monitoring have not been created, effective and logical mechanisms for soil quality control and responsibility for production by methods that lead to soil quality deterioration have not been developed.

The consequences of such actions or inaction were the systematic deterioration of the quantitative accounting of land, the actual lack of accounting for the quality of land. Practical lack of registration of landowners and land users, both in terms of their identification and in terms of purpose, types of use, areas of landowners and land users and the grounds for acquiring land rights and restrictions. The lack of these types of reliable and up-to-date information makes it impossible to build analytical reports, research and forecasts.

However, the Law of Ukraine, which opens the way to the introduction of the market of agricultural land, provides a number of restrictions on the subjectivity of market participants, the concentration of land, the conditions of collateral and the sale of collateral.

In addition, taking into account the formation of unified territorial communities and changes in the administrative division, these issues are of particular importance, as information in the database of the State Land Cadastre is stored on a territorial basis. That is why the lack of land monitoring and soil quality control will hinder the introduction of a fair market and will not allow timely assessment of trends, risks and dynamics of processes, including price parameters.

It should be borne in mind that large-scale production of modern tillage technologies involves the presence of large tracts of land and the homogeneity of 
crops. In the pursuit of large tracts of land and the straightness of field boundaries, farmers violate restrictions on the cultivation of land with steep slopes of more than 3 degrees and other restrictions that cause erosion and loss of fertile soil.

As the system of land monitoring and soil quality control in Ukraine is not maintained, there is no reliable information on the state of soil quality both in the country as a whole and in terms of individual territories.

Exercising the authority to manage land resources involves control over the quality of soils and the realization of the rights of the state as the owner, the rational use of land and increase soil fertility. Among the functions of land management - accounting and control over the efficiency of their use. Unfortunately, since 2016, even the quantitative accounting of land has been stopped.

It is necessary to take into account the importance of land resources for food security of the country.

Modern approaches in the world's leading countries to the land management system are aimed at creating information support and building on its basis an analytical system for making sound management decisions that are based more on economic than on administrative levers.

This monitoring should be carried out in the framework of creating a new technology for building an information model for all stakeholders and participants in the monitoring mode "online" with instant processing of interoperable data, which in turn allows you to display a reliable situation in real time.

This makes it extremely important to form and improve an automated land monitoring system at the national, regional and local levels, which in modern conditions should be based on the ideology of geospatial data infrastructure and automation of management processes.

The purpose of the study is to propose conceptual approaches to the functioning of the automated land monitoring system in Ukraine to ensure its implementation. 
Presentation of the main material. As a result of the study it was established that the automated information system of land monitoring (hereinafter - AIS) is aimed at providing public administration and local government systematized, reliable, operational information on the state of land and assess their change to develop proposals to prevent their negative impact on the powers of these bodies.

There is some debate around the definition of land monitoring, which we believe should be taken in a broad sense. Thus, the obligatory elements of land monitoring as a component of the state environmental monitoring system should be the assessment and control of processes related to qualitative soil changes, soil pollution with toxic substances, land transformation, etc. [1].

However, in the current conditions, the processes of socio-economic and legal nature regarding the distribution and use of land resources deserve special attention. Therefore, as part of land monitoring, it is necessary to monitor and control land transactions and their cost parameters. The role of the communicative component of land monitoring and ensuring transparency of land relations for the government and society is also increasing.

It is important to analyze the spatial distribution of changes in ownership and use of land. Thus, as we can see from the figure below, according to the OLX ad service, at the moment the main potential land transactions are concentrated in the area of influence of large cities and urban agglomerations of Ukraine. In fig. 1 shows more than 200 thousand ads for the sale of land, published in 2020. For such transactions we are interested in their attributive and spatial data: legal aspects, cost parameters, dynamics and trends of transformations [4]. 


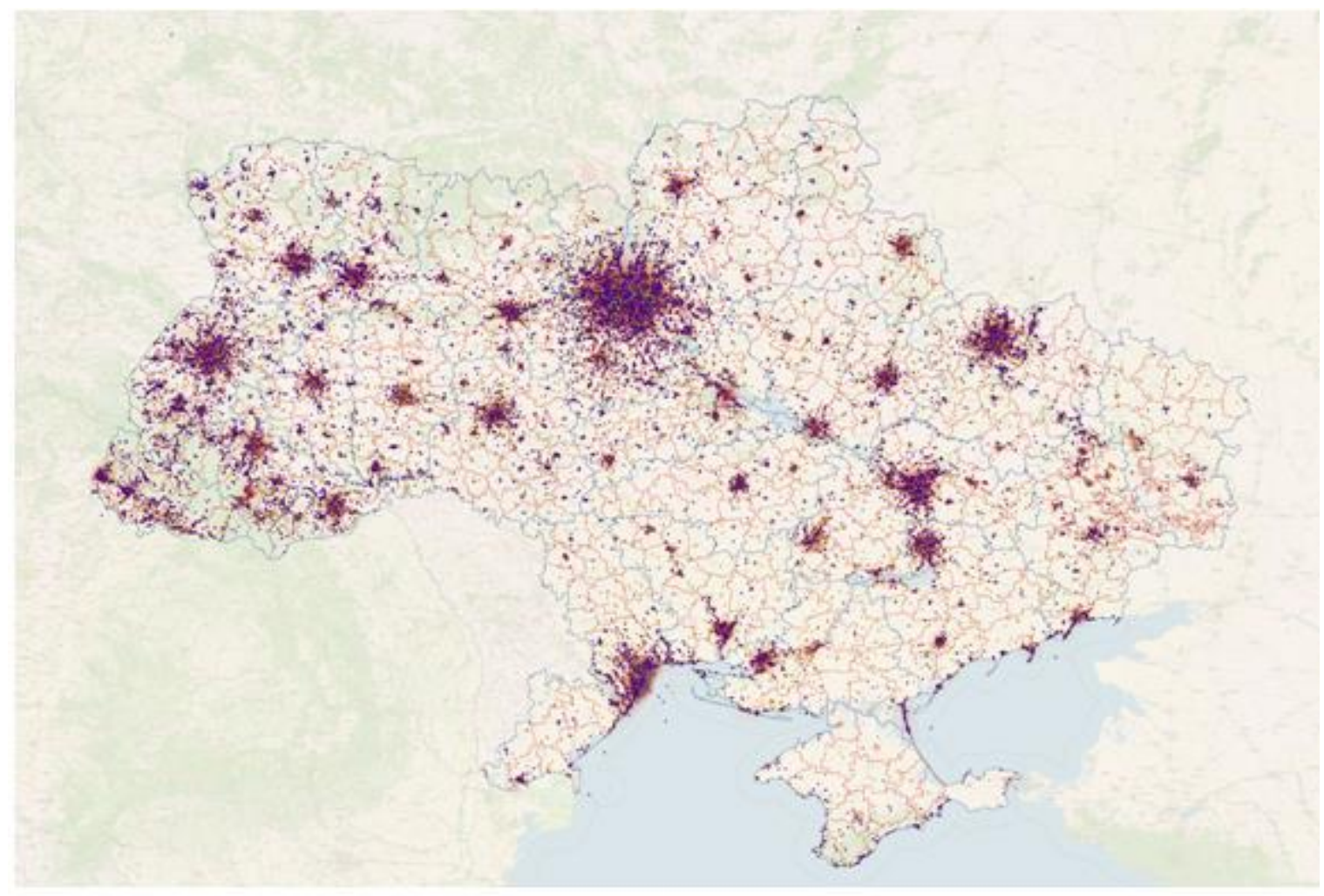

Fig. 1. Location of land plots put up for sale in 2020 on the electronic ads service olx.ua

Thus, AIS should become a universal tool for information support of organizational and management processes, effective management and use of information resources, a platform for communication between government and the public on the circulation of agricultural land. When automating land monitoring, the following tasks should be taken into account:

- collection, systematization, analysis of data on land resources; formation of analytical reports, graphs, charts, thematic maps and updating of basic spatial and attributive data on the state and changes in land tenure, land use and soil quality;

- monitoring of the market situation in real time according to certain indicators;

- monitoring the implementation of reservations on the land market, defined in current legislation;

- integration with the functions of geospatial modeling and analytical visualization; 
- organization of access of citizens, legal entities, local governments and state authorities to information resources of AIS land monitoring databases.

For all these and other positions, it is necessary to form a comprehensive database, which will be the basis for a wide range of analytics on standard queries and reports [5].

The purpose of creating an automated monitoring system is to identify the main approaches and requirements for periodic continuous, long-term monitoring of land condition, their circulation and soil quality, assessment and forecast of changes to identify negative processes and develop recommendations for their elimination or weakening. The introduction of the system is aimed at studying the state of land use efficiency, changing the legal status and ensuring control over compliance with the legal regime of land use, land use in ways that can lead to land degradation, control (monitoring) of soil quality, timely decision-making to prevent soil fertility, study and evaluation of land turnover processes, their indicators.

Among its main tasks: creation on the geoinformation database of the state land cadastre of the system of interaction with the database of real property rights and their restrictions, other information resources of the national level information-analytical system according to certain criteria and indicators. The definition of such criteria and indicators is done at the stage of developing requirements for the terms of reference.

Consideration should also be given to the automation of information and analytical activities for land monitoring in the following areas $[2,3,6]$ :

- monitoring of civil law transactions with land plots in terms of territories, forms of ownership, land categories, purpose;

- monitoring the dynamics of land prices in the relevant sections;

- monitoring of land use according to their category, purpose, types of land use;

- monitoring of the condition of lands by their quantitative and qualitative characteristics, including taking into account the results of observations of the condition of soils, their pollution by clogging, degradation, disturbance of lands; 
- assessment and forecasting of transformation (change) of land plots.

It is important to provide in the system the use of tools to ensure the reliability and updating of data, including by detecting anomalies and correcting errors in the data. As practice shows, many errors in the information of official registers are partly related to abuse and should be subject to careful control.

To this end, mechanisms for information interaction between all participants in the monitoring process and in-depth cross-analysis of interconnected data should be established in the monitoring system.

In fig. 2 presents the main conceptual framework that ensures the functioning of the automated land monitoring system. Their further detailing is carried out at the stage

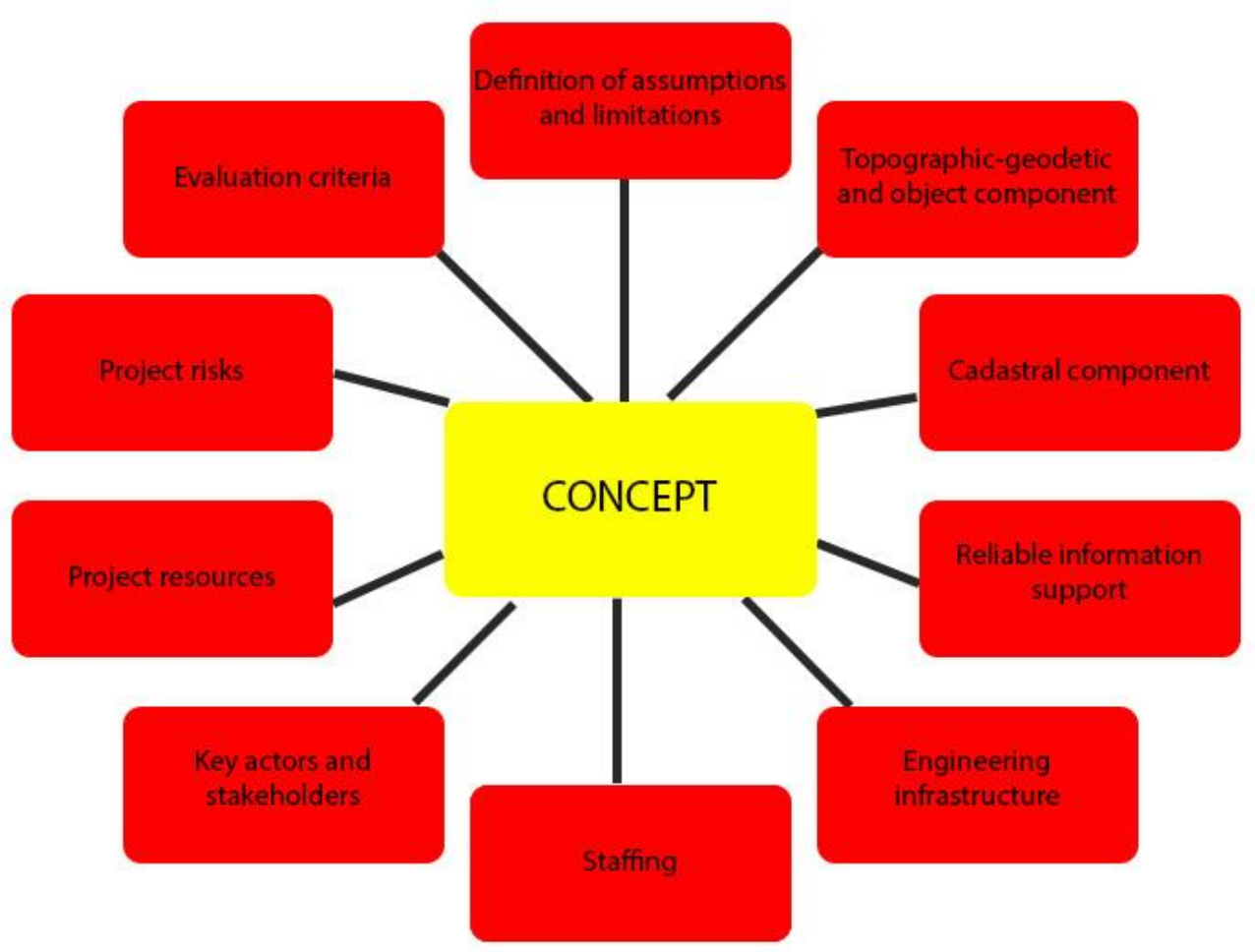
of developm ent of the technical task and the AIS project. 
Fig. 2. The structure of the problems to be solved at the stage of development of the concept of the automated information system of land monitoring

When developing AIS need to regulate: monitoring objects; criteria and indicators of monitoring objects; types and kinds of indicators; data standards; data formats; legislative and regulatory and organizational components; tools for ensuring the reliability and updating of data; data quality improvement tools.

AIS should be based on the principles and standards of the national geospatial data infrastructure and the European Union spatial data infrastructure, which is initiated by the European Commission and regulated by the INSPIRE Directive.

Conclusions. Modern world and domestic experience shows the widespread use of geographic information technologies for land management. The formation and improvement of an automated information system for land monitoring is an innovative response to current challenges in the Ukrainian economy, an important step in creating a platform for the transition to digital data and digital processes in land management at all levels. 


\section{References}

1. On approval of the Regulation on land monitoring. Resolution of the Cabinet of Ministers of Ukraine; Regulations of 20.08.1993 № 661.

2. Zakon Ukrayiny vid 25.10.2001 № 2768-III «Zemel'nyy kodeks Ukrayiny» [The law of Ukraine of October 26, 2001 № 2768-III «Land Code of Ukraine»]. (2001). Vidomosti Verkhovnoyi Rady Ukrayiny - Bulletin of the Verkhovna Rada of Ukraine, 3, 27 [in Ukrainian].

3. Zakon Ukrayiny vid 07.07.2011 № 3613-VI «Pro Derzhavnyy zemel'nyy kadastr» [The law of Ukraine of July 7, 2011 № 3613-VI «On the State Land Cadastre»]. (2012). Vidomosti Verkhovnoyi Rady Ukrayiny - Bulletin of the Verkhovna Rada of Ukraine, 8, 61 [in Ukrainian].

4. Dishlik, O. P., Dorosh, A. Y., Tarnopolsky, A. V., Tarnopolsky, E. A. (2018). Infrastruktura heoprostorovykh danykh v Ukrayini: stan ta metodolohichni problemy zakonodavchoho rehulyuvannya [Geospatial data infrastructure in Ukraine: position and methodological problems of legislative regulation]. Land management, cadastre and land monitoring, 1, 33-43 [in Ukrainian].

5. Tarnopolsky, A. V., Malashevsky, M. A., Tarnopolsky, E. A., Palamar, A. Y. (2018). Deyaki aspekty pobudovy infrastruktury heoprostorovykh danykh [Some aspects of a geospatial data infrastructure creation]. Young scientist, 2 (54), 28 - 31 [in Ukrainian].

6. Tarnopolskyi Y. Regarding the agricultural land turnover in Ukraine / Y. Tarnopolskyi, M. Malashevsky, A. Dorosh // Conduct of Modern Science 2019. Materials of the XV International Scientific And Practical Conference. 2019. - Volume 12. - P. 89-94.

\section{Дорош Й.М., Тарнопольський А.В., Ібатуллін Ш.І. КОНЦЕПТУАЛЬНІ ПІДХОДИ ФУНКЦІОНУВАННЯ \\ АВТОМАТИЗОВАНОЇ СИСТЕМИ МОНІТОРИНГУ ЗЕМЕЛЬ}

Анотація. Обгрунтовано цุілі та задачі ведення моніторингу земель та контролю якості грунтів, включаючи спостереження за господарським і правовим станом земель, їх 
обігом та якісним станом трунтів, оцінку і прогноз змін з метою забезпечення органів держсавного управління та місиевого самоврядування відповідною інформацією для розробки пропозииій та впровадження заходів з попередження негативних явищ $i$ тенденцій у землекористуванні.

Необхідність запровадження системи моніторингу земель зумовлено: систематичним погіршенням кількісного обліку земель, фактичною відсутністю обліку якості земель, вимогами розвитку ринкових земельних відносин.

Обтрунтовано необхідність врахування принципів $i$ стандартів національної інфраструктури геопросторових даних. Сформовано напрями, за якими результати моніторингу земель можуть бути використані для регулювання земельних відносин та прийняття управлінських рішень в щзодо землекористування та при формуванні обігу земельних ділянок.

Серед ключових питань, які необхідно врахувати при створенні системи моніторингу земель, визначено: необхідність застосування сучасних інформаційних технологій, перелік об’єктів моніторингу; атрибутивні дані об'єктів моніторингу; уніфіковані стандарти і формати даних; інструменти забезпечення достовірності та актуалізації даних, в тому числі шляхом виявлення аномалій та виправлення помилок у даних; механізми інформаційної взаємодї між усіма учасниками проиесу моніторингу.

Ключові слова: земельні ресурси, моніторинг земель, автоматизовані інформаційнокомунікативні системи, інфраструктура геопросторових даних, земельний кадастр, облік якості земель.

Дорош Й.М., Тарнопольский А.В., Ибатуллин Ш.И. КОНЦЕПТУАЛЬНЫЕ ПОДХОДЫ К ФУНКЦИОНИРОВАНИЮ АВТОМАТИЗИРОВАННОЙ СИСТЕМЫ МОНИТОРИНГА ЗЕМЕЛЬ

Обоснованы ияели и задачи ведения мониторинга земель и контроля качества почв, включая наблюдение за хозяйственным и правовым состоянием земель, их оборотом и качественным состоянием почв, оченку и прогноз изменений с иелью обеспечения органов государственного управления и местного самоуправления соответствующей информацией для разработки предложений и внедрения мероприятий по предупреждению негативных явлений и тенденций в землепользовании. 
Необходимость внедрения системы мониторинга земель обоснована: систематическим ухудшением количественного учета земель, фактическим отсутствием учета качества земель, требованиями развития рыночных земельных отномений.

Обоснована необходимость учета принципов и стандартов национальной инфраструктуры геопространственных данных. Сформированы направления, по которым результаты мониторинга земель могут быть использованы для регулирования земельных отномений $u$ принятия управленческих решений в отношении землепользования и при формировании оборота земельных участков.

Среди ключевых вопросов, которые необходимо учесть при создании системы мониторинга земель, определены: необходимость применения современных информационных технологий, перечень объектов мониторинга; атрибутивные данные объектов мониторинга; унифицированные стандарты и форматы данных; инструменты обеспечения достоверности и актуализации данных, в том числе путем выявления аномалий и исправления ошибок в данных; механизмы информачионного взаимодействия между всеми участниками процесса мониторинга.

Ключевые слова: земельные ресурсы, мониторинг земель, автоматизированные информационно коммуникативные системы, инфраструктура геопространственных данных, земельный кадастр, учет качества земель. 